\title{
Diagnostisk treffsikkerhet for hjertesvikt - data fra Akershus hjerteundersøkelse 2
}

\begin{abstract}
BAKGRUNN Å diagnostisere hjertesvikt i en vaktsituasjon kan være vanskelig. I internasjonale studier angis treffsikkerheten for en vaktlege til 0,76-0,90, målt med AUC lareal under ROC-kurve). I dette arbeidet har vi studert hvilken treffsikkerhet leger i indremedisinsk vakttjeneste ved et norsk universitetssykehus har når det gjelder å skille hjertesvikt fra ikke-hjertesvikt hos pasienter med pustebesvær.
\end{abstract}

MATERIALE OG METODE Vi samlet inn informasjon om 468 pasienter innlagt for pustebesvær ved Akershus universitetssykehus i perioden juni 2009 til november 2010. 314 pasienter ble inkludert. Vaktlegen anga sannsynlighet for hjertesvikt (0-100\%) før resultatet av måling av NT-proBNP-konsentrasjon (N-terminal pro-B-type natriuretisk peptid) forelå. Endelig diagnose ved aktuell sykehusinnleggelse ble stilt retrospektivt av to uavhengige leger etter gjennomgang av pasientjournal, supplerende undersøkelser og pasientutfall.

RESULTATER Hjertesvikt var årsak til innleggelse hos 143 pasienter (46\%). Hjertesviktpasientene var eldre, oftere menn, hadde høyere prevalens av hjertesykdom, dårligere nyrefunksjon og høyere NT-proBNP-konsentrasjon enn pasienter med annen diagnose. Vaktlegenes treffsikkerhet for diagnosen hjertesvikt var AUC 0,86 (95\% KI 0,82-0,90). Det var lavere treffsikkerhet når pasienten hadde hjertesvikt med venstre ventrikkel-ejeksjonsfraksjon (EF) $\geq 50 \%(n=52)$ - da var AUC $0,83(0,77-0,87)$.

FORTOLKNING Treffsikkerheten til vaktlegene ved Akershus universitetssykehus i perioden 2009-10 var like god som treffsikkerheten rapportert fra internasjonale sentre når det gjaldt diagnostisering av hjertesvikt. Treffsikkerheten var lavere for hjertesviktpasienter med ejeksjonsfraksjon $\geq 50 \%$.

Det er vist at ved hjertesvikt gir tidlig diagnose redusert sykelighet og lavere dødelighet (1). Samtidig kan diagnostikken være vanskelig, da kliniske funn ikke nødvendigvis korrelerer med objektive parametre for hjertets funksjon (2). EKG-undersøkelse og røntgen thorax har også moderat sensitivitet og spesifisitet når det gjelder hjertesvikt - i Breathing Not Properly-studien var for eksempel sensitiviteten $58 \%$ og spesifisiteten $78 \%$ for avvikende EKG, for kardiomegali på røntgen thorax var sensitiviteten $79 \%$ og spesifisiteten $80 \%$ (3). Ekkokardiografi krever spesialkompetanse, og svar på måling av B-type natriuretiske peptider vil ikke foreligge umiddelbart dersom analysen blir kjørt i laboratorium.

Det er publisert flere studier om akuttmottaklegers treffsikkerhet når det gjelder hjertesvikt. Internasjonalt har de en treffsikkerhet på 0,76-0,90, målt som areal under kurven (AUC) ved ROC-test (receiver operating characteristics) (4-8). Vi er ikke kjent med at tilsvarende målinger er gjort ved norske akuttmottak. Vi ønsket således med dette arbeidet å studere hvor treffsikre leger i indremedisinsk vakttjeneste ved et norsk universitetssykehus var når det gjaldt å skille hjertesvikt fra ikke-hjertesvikt hos pasienter med pustebesvær.

\section{Materiale og metode \\ Studiepopulasjon}

Vi inkluderte totalt 314 pasienter innlagt med pustebesvær ved Medisinsk divisjon, Akershus universitetssykehus, fra mandag til torsdag kl 0800-1400 i perioden juni 2009november 2010 i studien Akershus hjerteundersøkelse 2 (ACE 2-studien). Inklusjonskriteriene var samtykkekompetent pasient $\geq 18$ år med pusteproblemer vurdert som hovedårsak til innleggelsen. Det måtte være gått $<24$ timer fra innleggelse i sykehuset til studieinklusjon.

Studien ble gjennomført i henhold til Helsinkierklæringen og er godkjent av regional etisk komité (5.2008.2832) og Akershus universitetssykehus. Alle pasientene ga skriftlig samtykke til deltakelse i studien etter å ha fått muntlig og skriftlig informasjon.

\section{Datainnsamling}

Vi samlet inn informasjon om NYHA-funksjonsklasse (New York Heart Association) og funn ved klinisk undersøkelse for alle pasientene direkte fra vaktlege ved hjelp av et standardisert spørreskjema, senest ved starten av legenes rapportmøte etter vakt. Vi ba ikke om skjema for pasienter med kjent alvorlig kreftsykdom og forventet kort levetid, pasienter med hjerteinfarkt, koronar intervensjon eller

\author{
Jon Brynildsen \\ Arne Didrik Høiseth \\ Medisinsk divisjon \\ Akershus universitetssykehus \\ og \\ Senter for hjertesviktforskning \\ og K.G. Jebsen-senter for hjerteforskning \\ Institutt for klinisk medisin \\ Universitetet i Oslo
}

\section{Ståle Nygård}

Institutt for eksperimentell medisinsk forskning Oslo universitetssykehus, Ullevål

og

Senter for hjertesviktforskning

og K.G. Jebsen-senter for hjerteforskning

Institutt for klinisk medisin

Universitetet i Oslo

\section{Tor-Arne Hagve}

Tverrfaglig laboratoriemedisin og medisinsk biokjemi

Divisjon for diagnostikk og teknologi

Akershus universitetssykehus

og

Institutt for klinisk medisin

Universitetet i Oslo

\section{Geir Christensen}

Institutt for eksperimentell medisinsk forskning Oslo universitetssykehus, Ullevål

og

Senter for hjertesviktforskning

og K.G. Jebsen-senter for hjerteforskning

Institutt for klinisk medisin

Universitetet i Oslo

\section{Torbjørn Omland}

Medisinsk divisjon

Akershus universitetssykehus

og

Senter for hjertesviktforskning

og K.G. Jebsen-senter for hjerteforskning

Institutt for klinisk medisin

Universitetet i Oslo

\section{Helge Røsjø}

helge.rosjo@medisin.uio.no

Medisinsk divisjon

Akershus universitetssykehus

og

Senter for hjertesviktforskning

og K.G. Jebsen-senter for hjerteforskning

Institutt for klinisk medisin

Universitetet i Oslo

e-tab 1, e-tab 2, e-tab 3 og e-tab 6 finnes

i Tidsskriftets elektroniske utgaver 


\section{HOVEDBUDSKAP}

Vaktlegene ved Akershus universitetssykehus hadde like god treffsikkerhet $\mathrm{i}$ å diagnostisere akutt hjertesvikt hos pasienter med akutt pustebesvær som det som tidligere er rapportert fra ledende internasjonale sentre

Vaktlegene hadde dårligere diagnostisk treffsikkerhet hos hjertesviktpasienter med bevart venstre ventrikkel-ejeksjonsfraksjon enn hos hjertesviktpasienter med redusert venstre ventrikkel-ejeksjonsfraksjon

Kombinasjonen av legevurdering og NTproBNP-måling ga best treffsikkerhet i å diagnostisere hjertesvikt omfattende kirurgi de siste to uker og pasienter med hemoglobinnivå $<10 \mathrm{~g} / 100 \mathrm{ml}$ (eksklusjonskriterier). Totalt fylte 94 ulike leger ut skjemaer (e-tab 1, e-tab 2).

Vaktlegene ble spesifikt bedt om å angi sannsynligheten fra $0 \%$ til $100 \%$ for akutt hjertesvikt som årsak til pasientens pustebesvær, analogt til strategien brukt for liknende studier tidligere (4-8). De hadde tilgang til supplerende undersøkelser og journalopplysninger (inkludert ev. tidligere hjerteutredning) før de anga sannsynlighetsgrad, men ikke til NT-proBNP-konsentrasjon (N-terminal pro-B-type natriuretisk peptid) målt ved den aktuelle innleggelsen. Blodtrykk, hjertefrekvens og kroppstemperatur ble målt ved innleggelse.

$\mathrm{Vi}$ innhentet informasjon om aktuelle sykdomsforløp, tidligere sykdommer og medikamenter direkte fra pasientene. Dette ble sjekket opp mot journalen. Koronarsykdom ble definert som tidligere hjerteinfarkt eller angiografisk påvist koronarstenose $>50 \%$. Paroksystisk og kronisk atrieflimmer ble klassifisert sammen. Data fra ekkokardiografi ble registrert fra pasientens journal.

\section{Fastsetting av diagnose}

Innleggelsesdiagnosen ble bestemt retrospektivt av to spesialister i indremedisin
(ADH, TO). De hadde tilgang til alle medisinske opplysninger, inkludert oppfølgingsdata (median oppfølging 464 dager før diagnosesetting som var fullført desember 2012), men de hadde ikke tilgang til resultater fra forskningsbiobanken som ble samlet for ACE 2-studien. De arbeidet uavhengig av hverandre, og ved uenighet om diagnosen fastsatte de den ved konsensus. Dette er analogt til strategien som har vært brukt i andre studier tidligere (4-8).

Hjertesvikt ble diagnostisert på bakgrunn av etablerte kriterier med symptomer og tegn på hjertesvikt samt objektive funn på strukturell eller funksjonell myokarddysfunksjon ved ekkokardiografi (9).

Innleggelsene ble klassifisert som:

- hjertesviktinnleggelse

- annen årsak til innleggelse enn hjertesvikt, men myokarddysfunksjon (f.eks. pneumoni hos pasient med kronisk hjertesvikt)

- annen årsak til pustebesvær og normal hjertefunksjon.

Denne inndelingen er også brukt i tidligere studier (4-7). De to siste gruppene ble klassifisert sammen som ikke-hjertesvikt (fig 1).

Hjertesviktpasientene ble inndelt etter redusert venstre ventrikkel-ejeksjonsfraksjon

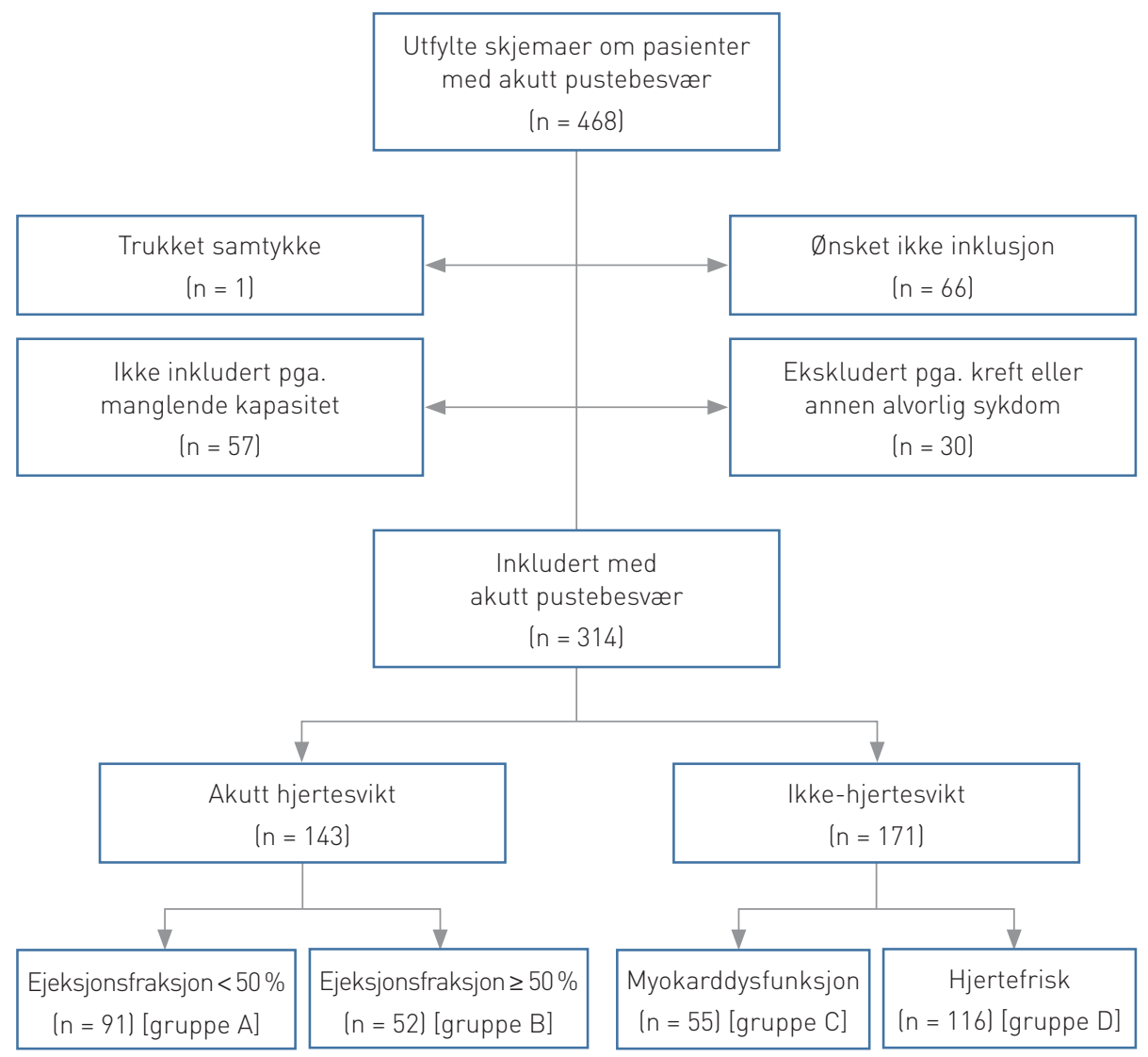

Figur 1 Flytskjema for diagnosesetting i studien 
Vaktlegenes angivelse av sannsynlighetsgrad (\%)

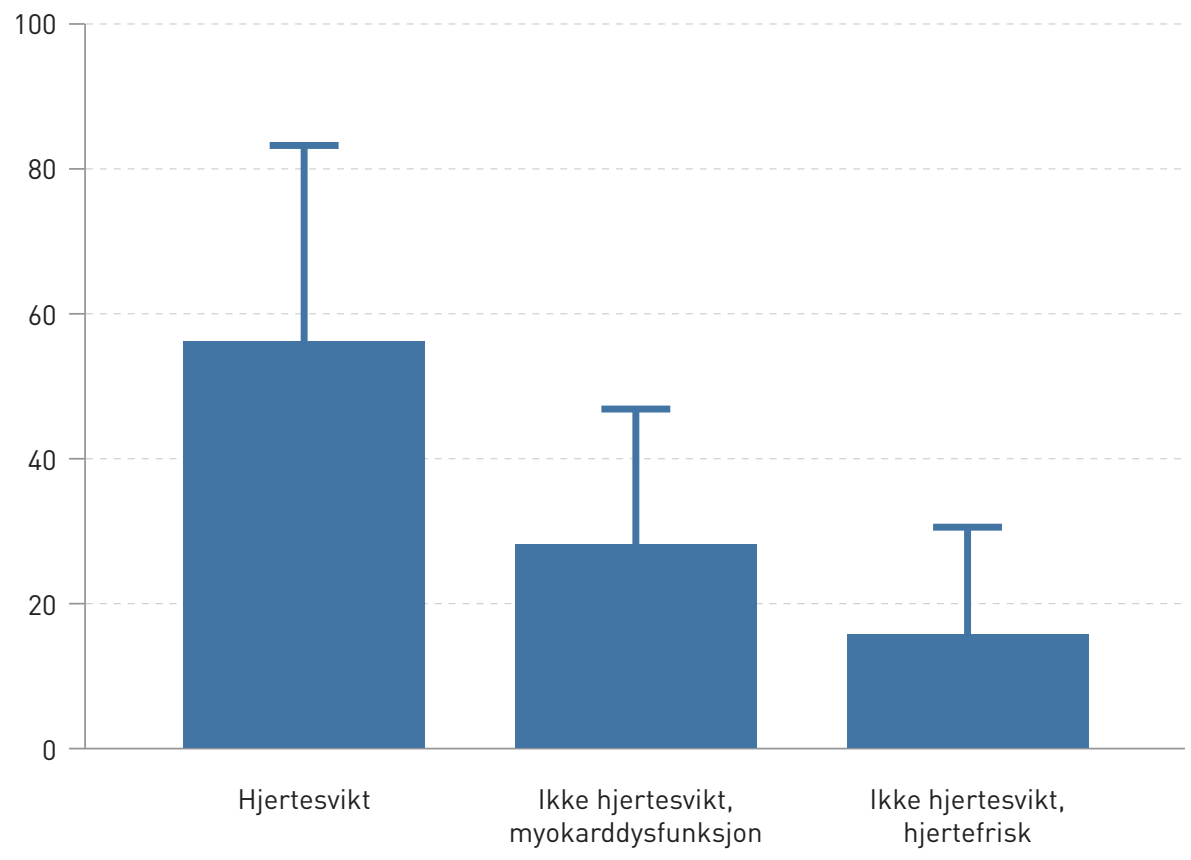

Figur 2 Sannsynlighet for hjertesvikt som angitt av vaktlegene inndelt etter diagnose fra endepunktkomité. Data er angitt som histogram med gjennomsnitt og standardavvik

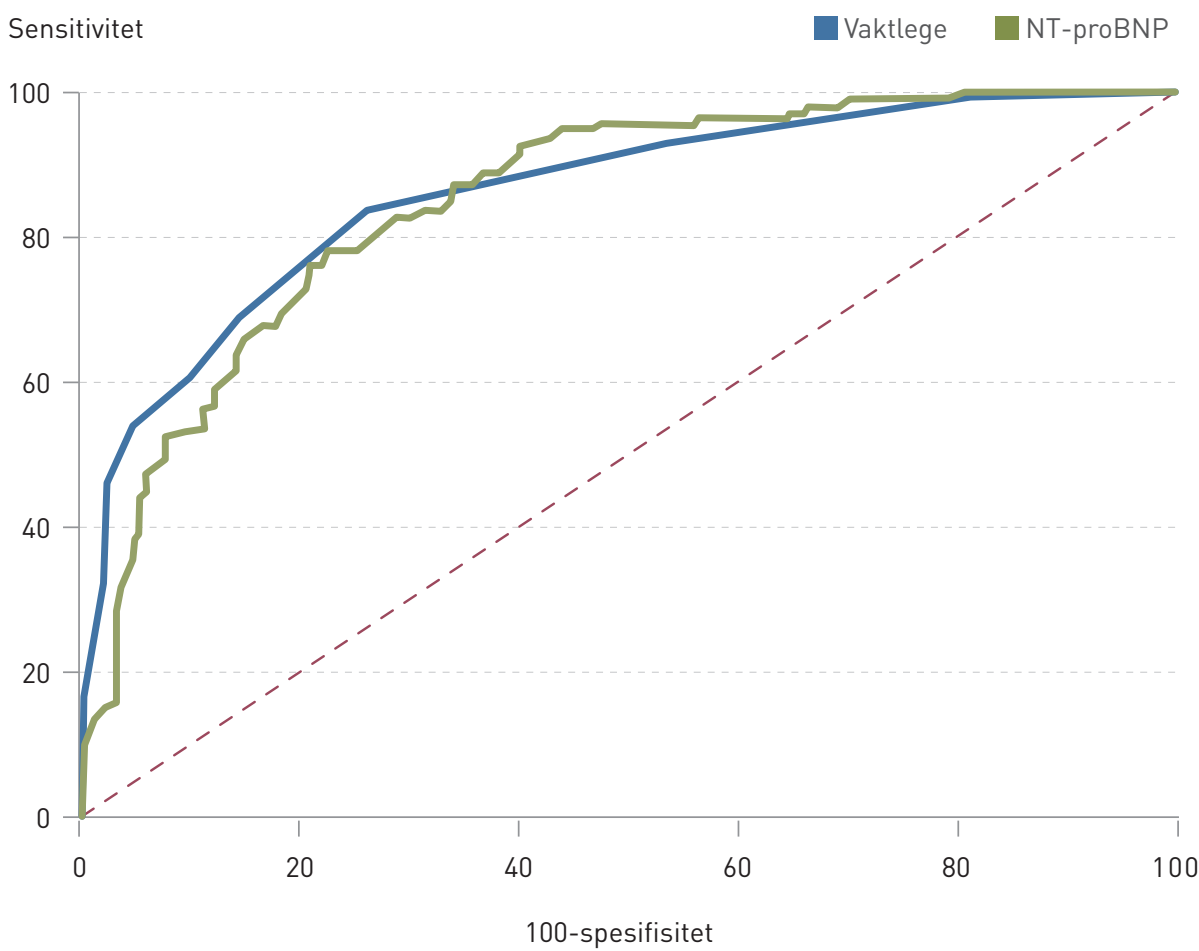

Figur 3 Diagnostisk treffsikkerhet for hjertesvikt for vaktleger (\%) og NT-proBNP (pmol/l) angitt ved ROCkurve
$(\mathrm{EF}<50 \% ; \mathrm{n}=91)$ eller bevart venstre ventrikkel-ejeksjonsfraksjon $(\mathrm{EF} \geq 50 \% ; \mathrm{n}=52)$ (fig 1). I den siste gruppen hadde pasientene funn forenlig med myokarddysfunksjon eller -skade, som angitt i e-tabell 3.

\section{Biokjemiske analyser}

NT-proBNP-verdier ble målt i EDTA-plasmaprøver (etylendiamintetraacetat), som ble tatt innen 24 timer fra innleggelsestidspunktet (ProBNP II, Roche Diagnostics, Penzberg, Tyskland). Kreatinin og hemoglobin ble målt ved innleggelsen ved hjelp av standard biokjemiske metoder. Kreatininclearance ble regnet ut ved hjelp av Cockcroft-Gaults formel (10).

\section{Statistikk}

Kontinuerlige data er presentert som gjennomsnitt \pm standardavvik eller median (kvartil 1-3) for variabler som avviker fra normalfordelingen (vurdert ved Kolmogorov-Smirnovs test). Forskjeller mellom grupper ble undersøkt med t-test eller MannWhitneys U-test. Kategoriske data er oppgitt $i$ absolutte tall og prosentverdier og sammenliknet ved hjelp av khikvadrattest. Variablene ble undersøkt for assosiasjon med hjertesvikt ved hjelp av logistisk regresjonsanalyse, der oddsratio (OR) blir angitt med 95\% konfidensintervall (KI).

Diagnostisk treffsikkerhet for hjertesvikt mot ikke-hjertesvikt ble vurdert med ROCkurveanalyse (11), ved å angi arealet under kurven (AUC) med $95 \%$ KI. En ROC-kurve er en grafisk fremstilling av korrekt positiv rate (sensitivitet) mot falskt positiv rate (1-spesifisitet), og AUC representerer sannsynligheten for at testen angir en høyere tallverdi for en som har tilstanden (kasus) enn for en som ikke har tilstanden (kontrollperson). En perfekt test har AUC $=1,0$ og en helt uspesifikk test (f.eks. det å kaste mynt eller krone) har AUC $=0,5$.

Hovedendepunktet var vaktlegenes evne til å skille hjertesvikt fra ikke-hjertesvikt i hele pasientmaterialet $(n=314)$. Vi ønsket også å studere deres treffsikkerhet når det gjaldt diagnosen hjertesvikt hos hjertesviktpasienter med henholdsvis ejeksjonsfraksjon $<50 \%$ (fig 1, gruppe A) og ejeksjonsfraksjon $\geq 50 \%$ (fig 1, gruppe B) og ved å sammenlikne hjertesviktpasienter med pasienter der hjertefunksjonen ble vurdert som normal (fig 1, gruppe D). En p-verdi $<0,05$ ble vurdert som statistisk signifikant.

Statistiske analyser ble utført med SPSS for Windows versjon 20.0 (SPSS, Chicago, IL, USA), med unntak av sammenlikning av ROC/AUC, som ble gjort med MedCalc for Windows, versjon 12.1.4.0 (MedCalc Software, Mariakerke, Belgia) og det statistiske programmeringsspråket R (R Development Core Team, 2008). Variabler ble undersøkt én og én for assosiasjon med hjertesvikt. 


\section{Resultater}

Pasientkarakteristika

De to spesialistene stilte samme diagnose hos 298 av 314 pasienter ( $95 \%$ ). Totalt ble 143 innleggelser (46\%) klassifisert under hjertesvikt. Av pasienter med annen hovedårsak til pustebesvær enn hjertesvikt hadde $55(32 \%)$ samtidig tegn på myokarddysfunksjon (fig 1, gruppe C).

Hjertesviktpasientene skilte seg fra de andre pasientene med pustebesvær når det gjaldt flere demografiske (tab 4) og kliniske variabler (tab 5). 51\% av dem med hjertesvikt anga langvarig pustebesvær $(>7 \mathrm{~d})$, mot $30 \%$ i gruppen av pasienter uten hjertesvikt $(\mathrm{p}=0,01)$. Gjennomsnittlig ejeksjonsfraksjon var $41 \pm 13 \%$ hos pasientene med hjertesvikt uansett type, mot $33 \pm 8 \%$ hos pasientene med systolisk dysfunksjon (fig 1, gruppe A), og 52 av 143 pasienter med hjertesvikt (36\%) hadde en ejeksjonsfraksjon $\geq 50 \%$ (fig 1, gruppe B).

NT-proBNP-konsentrasjonen var høyere ved hjertesvikt (tab 5). Flere symptomer og kliniske tegn var assosiert med hjertesvikt, i tillegg var det en robust assosiasjon mellom økende NT-proBNP-konsentrasjon og hjertesvikt (e-tab 6).

\section{Vaktlegenes diagnostiske treffsikkerhet}

Vaktlegene anga høyere sannsynlighet (på en skala fra $0 \%$ til $100 \%$ ) for hjertesvikt hos dem som var klassifisert i hjertesviktgruppen av endepunktkomiteen enn hos de andre pasientene $-56 \pm 27 \%$ mot $20 \pm 17 \%, \mathrm{p}<0,001$ (fig 2). Vaktlegenes treffsikkerhet når det gjaldt å skille pasienter med hjertesvikt fra andre pasienter, uttrykt som AUC, var 0,86 (95\% KI 0,82-0,90) (fig 3).

I analyser der vi har skilt mellom hjertesviktpasienter med ejeksjonsfraksjon over og under $50 \%$, fant vi at vaktlegene anga høyere sannsynlighet for hjertesvikt hos dem med ejeksjonsfraksjon $<50 \%$ (fig 1 , gruppe $\mathrm{A}$ $(n=91))$ enn hos dem med ejeksjonsfraksjon $\geq 50 \%$ (fig 1, gruppe B $(\mathrm{n}=52)$ ): $61 \pm 27 \%$ mot $48 \pm 25 \%, \mathrm{p}=0,005$. AUC var 0,88 $(0,84-0,92)$ for vaktlegenes evne til å skille mellom hjertesviktpasienter med ejeksjonsfraksjon $<50 \%$ (gruppe $\mathrm{A}$ ) og pasienter uten hjertesvikt, mens AUC var 0,83 (0,77-0,87) for å skille mellom hjertesviktpasienter med ejeksjonsfraksjon $\geq 50 \%$ (gruppe B) og pasienter uten hjertesvikt.

For gruppen av pasienter som hadde pustebesvær av annen årsak enn hjertesvikt $(\mathrm{n}=171)$, anga vaktlegene høyere sannsynlighet for hjertesvikt for dem med tegn til myokarddysfunksjon $(n=55)$ enn for dem med helt normal hjertefunksjon $(\mathrm{n}=116)$ : $28 \pm 19 \%$ versus $15 \pm 15 \%, \quad \mathrm{p}<0,001$ (fig 2). AUC var $0,90(0,85-0,93)$ for vaktlegenes evne til å skille mellom hjertesviktpasienter $(n=143)$ og pasienter med puste-

Tabell 4 Karakteristika ved pasienter innlagt med pustebesvær og inkludert i ACE 2-studien. Antall (\%) der annet ikke er angitt

\begin{tabular}{|c|c|c|c|}
\hline & $\begin{array}{c}\text { Akutt } \\
\text { hjertesvikt } \\
(\mathrm{n}=143)\end{array}$ & $\begin{array}{c}\text { Ikke-hjerte- } \\
\text { svikt } \\
(n=171)\end{array}$ & P-verdi \\
\hline $\begin{array}{l}\text { Alder lår) } \\
\text { (gjennomsnitt } \pm \text { standardavvik) }\end{array}$ & $75 \pm 11$ & $66 \pm 15$ & $<0,001$ \\
\hline Mannlig kjønn & 90 (63) & $74 \quad(43)$ & 0,001 \\
\hline $\begin{array}{l}\text { Kroppsmasseindeks (BMI) }\left(\mathrm{kg} / \mathrm{m}^{2}\right) \\
\text { (gjennomsnitt } \pm \text { standardavvik) }\end{array}$ & $27 \pm 6$ & $26 \pm 8$ & 0,79 \\
\hline NYHA-funksjonsklasse & & & 0,42 \\
\hline I & $0 \quad(0)$ & $0 \quad(0)$ & \\
\hline ॥ & $23(16)$ & $36 \quad(21)$ & \\
\hline III & 55 (39) & 64 (37) & \\
\hline IV & $65 \quad(46)$ & $71 \quad(42)$ & \\
\hline $\begin{array}{l}\text { Ejeksjonsfraksjon (EF) (\%) } \\
\text { (gjennomsnitt } \pm \text { standardavvik) }\end{array}$ & $41 \pm 13$ & & \\
\hline Hjertesvikt (EF < 50\%) & $91 \quad(64)$ & & \\
\hline Hjertesvikt (EF ${ }^{3} 50 \%$ ) & 52 (36) & & \\
\hline Hoste ved innleggelse & 85 (59) & 126 & 0,007 \\
\hline Røyking & & & 0,08 \\
\hline Nei, aldri & 39 (27) & $38 \quad(22)$ & \\
\hline $\begin{array}{l}\text { Nei, men har røykt tidligere } \\
\text { (sluttet > } 3 \text { md. siden) }\end{array}$ & $74 \quad(52)$ & $78 \quad(46)$ & \\
\hline Ja, inkludert de siste $3 \mathrm{md}$. & $30 \quad(21)$ & 55 (32) & \\
\hline \multicolumn{4}{|l|}{ Historie med } \\
\hline Hjertesvikt & $87 \quad(61)$ & $14 \quad(8)$ & $<0,001$ \\
\hline Koronarsykdom & $77 \quad(54)$ & 33 (19) & $<0,001$ \\
\hline Hjerteinfarkt & $65 \quad(46)$ & $30 \quad(18)$ & $<0,001$ \\
\hline Koronar revaskularisering & $54 \quad(38)$ & $21 \quad(12)$ & $<0,001$ \\
\hline Hypertensjon & $69 \quad(48)$ & $51 \quad(30)$ & 0,001 \\
\hline $\begin{array}{l}\text { Kronisk eller paroksysmal atrie- } \\
\text { flimmer }\end{array}$ & $68 \quad(48)$ & $28 \quad(16)$ & $<0,001$ \\
\hline Diabetes mellitus & 43 (30) & 25 (15) & 0,001 \\
\hline Kols & $61 \quad(43)$ & $94 \quad(55)$ & 0,03 \\
\hline Angina pectoris & 35 (25) & $16 \quad(9)$ & $<0,001$ \\
\hline Astma & $6 \quad$ (4) & 22 (13) & 0,007 \\
\hline
\end{tabular}

besvær uten nedsatt hjertefunksjon (fig 1, gruppe D).

\section{NT-proBNP-konsentrasjon og hjertesvikt}

NT-proBNP-konsentrasjonen var signifikant høyere hos pasienter med hjertesvikt enn hos de andre : median 424 pmol/l (kvartil 1-3 188-988 pmol/l) mot $41 \mathrm{pmol} / 1$
(14-134 pmol/1), p < 0,001. AUC for å skille hjertesvikt fra ikke-hjertesvikt ved hjelp av NT-proBNP i hele materialet var $0,85(0,81-0,89)$ (fig 3$)$.

I analyser der vi har skilt mellom hjertesviktpasienter med ejeksjonsfraksjon over og under $50 \%$, fant vi at NT-proBNP-konsentrasjonen var høyere hos dem med ejek- 
Tabell 5 Funn ved klinisk unders $ø$ kelse, som vurdert av vaktlege, og supplerende undersøkelser inndelt etter diagnose for pasienter med pustebesvær inkludert i ACE 2-studien. Antall (\%) der ikke annet er angitt

\begin{tabular}{|c|c|c|c|}
\hline & $\begin{array}{l}\text { Hjertesvikt } \\
(n=143)\end{array}$ & $\begin{array}{l}\text { Ikke-hjertesvikt } \\
\quad(n=171)\end{array}$ & P-verdi \\
\hline Hjertefrekvens (slag/min) (gjennomsnitt \pm standardavvik) & $92 \pm 26$ & $94 \pm 21$ & 0,44 \\
\hline Diastolisk blodtrykk (mm Hg) (gjennomsnitt \pm standardavvik) & $82 \pm 18$ & $78 \pm 15$ & 0,04 \\
\hline Systolisk blodtrykk (mm Hg) (gjennomsnitt \pm standardavvik) & $147 \pm 32$ & $145 \pm 26$ & 0,003 \\
\hline Respirasjonsfrekvens (per min) > 16 & 109 (76) & 137 (81) & 0,62 \\
\hline Feber $\left(>38^{\circ} \mathrm{C}\right)$ & $9 \quad 16)$ & $28 \quad(16)$ & 0,006 \\
\hline Halsvenestuvning & $17 \quad(12)$ & $8 \quad(5)$ & 0,019 \\
\hline \multicolumn{4}{|l|}{ Bilyd ved hjerteauskultasjon } \\
\hline Systolisk bilyd & 38 (27) & $8 \quad(5)$ & $<0,001$ \\
\hline Dempning lunger & & & 0,016 \\
\hline Ingen & 101 (71) & 142 (83) & \\
\hline Nedre tredel & $30 \quad(21)$ & $17 \quad(10)$ & \\
\hline Midt/øvre & 12 (8) & 12 (7) & \\
\hline Krepitasjoner lunger & & & 0,21 \\
\hline Ingen & $60 \quad(42)$ & $91 \quad(53)$ & \\
\hline Nedre tredel & $52(36)$ & $54 \quad(32)$ & \\
\hline Midt/øvre & $31 \quad(22)$ & $26 \quad(15)$ & \\
\hline Pipelyd lunger & 35 (25) & $74 \quad(43)$ & $<0,001$ \\
\hline Hepatomegali & $816)$ & $3 \quad(2)$ & 0,027 \\
\hline Perifere ødemer & 77 (54) & $47 \quad(28)$ & $<0,001$ \\
\hline Avvikende EKG & 118 (83) & 105 (62) & $<0,001$ \\
\hline Kreatininclearance (ml/min) (gjennomsnitt \pm standardavvik) & $66 \pm 39$ & $89 \pm 50$ & $<0,001$ \\
\hline $\begin{array}{l}\text { Sannsynlighet for hjertesvikt angitt av vaktlege (\%) } \\
\text { (gjennomsnitt } \pm \text { standardavvik) }\end{array}$ & $56 \pm 27$ & $20 \pm 17$ & $<0,001$ \\
\hline NT-proBNP-konsentrasjon (pmol/l) median (kvartil 1-3) & $424 \quad(188-988)$ & $41 \quad(14-134)$ & $<0,001$ \\
\hline
\end{tabular}

sjonsfraksjon $<50 \%$ (fig 1, gruppe A) enn hos dem med ejeksjonsfraksjon $\geq 50 \%$ (fig 1, gruppe B): $507 \mathrm{pmol} / 1(243-1028$ $\mathrm{pmol} / \mathrm{l})$ versus $270 \mathrm{pmol} / \mathrm{l}(81-538 \mathrm{pmol} / \mathrm{l})$, $\mathrm{p}=0,001$. Kombinasjonen av vaktlegevurdering og NT-proBNP-måling ga høyere AUC enn hver av variablene alene for å skille hjertesvikt fra ikke-hjertesvikt. Det gjaldt både når hjertesviktpasientene hadde ejeksjonsfraksjon $<50 \%$ (fig 1, gruppe A; AUC 0,92 (0,89-0,96)) og når de hadde ejeksjonsfraksjon $\geq 50 \%$ (fig 1 , gruppe $\mathrm{B}$; AUC 0,84 (0,78-0,91)).

\section{Diskusjon}

Hovedfunnet $i$ vår studie er at vaktlegene ved Akershus universitetssykehus hadde like høy treffsikkerhet for diagnosen hjerte- svikt som det som er rapportert $\mathrm{i}$ internasjonale studier fra ledende sentre (4-8). Treffsikkerheten var dårligere når det gjaldt å stille diagnosen hjertesvikt hos hjertesviktpasienter med bevart venstre ventrikkelejeksjonsfraksjon.

Organiseringen av legetjenesten i akuttmottak varierer mellom ulike land. I Norge har tradisjonelt turnusleger og leger i utdanningsstillinger vært mottakende lege for pasienter med akutt pustebesvær. Dette var også modellen ved Akershus universitetssykehus i den aktuelle perioden, som vist $\mathrm{i}$ e-tabell 2.

Vaktlegene i vår studie viser tilsvarende treffsikkerhet for akutt hjertesvikt som rapportert i store multisenterstudier som Breathing Not Properly $(\mathrm{AUC}=0,86)(6)$ og
IMPROVE-CHF (AUC $=0,83)$ (7). Treffsikkerhet når det gjelder NT-proBNP-måling for å skille hjertesvikt fra ikke-hjertesvikt var også like høy i vår studie som i internasjonale multisenterstudier (7).

Vi finner også at kombinasjonen av legevurdering og måling av NT-proBNP gir bedre diagnostisk treffsikkerhet enn hver av disse variablene alene, noe som tidligere også er funnet for B-type natriuretiske peptider i andre studier (5-7). Våre funn og resultater fra andre studier (12) tyder på at anamnestiske opplysninger gir viktig informasjon når man skal vurdere sannsynligheten for hjertesvikt, mens det man finner ved en klassisk klinisk undersøkelse har sine begrensninger.

Vaktlegene $\mathrm{i}$ vår studie treffer ganske bra 
med tanke på hjertesvikt, men angir lavere sannsynlighet for dette hos hjertesviktpasientene med bevart venstre ventrikkel-ejeksjonsfraksjon. Det er viktig å være oppmerksom på denne tilstanden, da prevalensen av hjertesvikt med bevart ejeksjonsfraksjon øker i befolkningen (13).

Prognosen ved hjertesvikt med bevart ejeksjonsfraksjon er sammenliknbar med prognosen ved hjertesvikt med redusert ejeksjonsfraksjon, og det finnes i dag ingen behandling som er vist å gi bedre overlevelse (13). Hjertesviktpasienter med ejeksjonsfraksjon $\geq 50 \%$ er oftere kvinner og eldre enn hjertesviktpasienter med ejeksjonsfraksjon $<50 \%$, mens funnene ved klinisk undesøkelse ser ut til å være like ved de to hjertesvikttypene (14). Opplysninger og funn som kan passe med hjertesvikt bør derfor utløse sterk mistanke om venstresidig svikt, også hos pasienter med normal venstre ventrikkel-ejeksjonsfraksjon, inkludert pasienter med kjent kols (15).

Vår studie har styrker og svakheter. Vi gjennomførte den etter tilsvarende protokoll som er i internasjonale studier, noe som muliggjør sammenlikning av resultater. Hjertesvikt er et syndrom som ikke kan diagnostiseres ut fra én enkelt ekkokardiografisk variabel. Vi fulgte derfor anbefalingen om at man i slike studier bør bedømme alle innleggelser ved hjelp av en endepunktkomité (12), noe man har gjort tidligere (4-8).

Vår endepunktkomité klassifiserte pasientene med større samsvar enn det som er funnet $\mathrm{i}$ de fleste andre studier der dette er oppgitt $(5,6)$. Resultatene våre avviker heller ikke fra litteraturen med tanke på kliniske funn og resultater for NT-proBNP, slik at feilklassifisering trolig ikke er noe stort problem i vår studie.

Vi inkluderte pasienter i perioden 2009-10, men hjertesviktdiagnostikken er ikke betydelig endret siden den gang. Det er anbefalt tidlig ekkokardiografi ved mistanke om hjertesvikt (16), men dette forutsetter at legen i akuttmottaket oppfatter at hjertesvikt er en potensiell diagnose.

I en dansk studie var det bedre treffsikkerhet ved tidlig ultralyd hos uselekterte pasienter med pustebesvær, men i denne studien gjorde en øvet operatør alle ultralydundersøkelsene (17). Det er også vist at lommeultralydapparater bedrer diagnostikken av uselekterte pasienter hvis undersøkelsene utføres av øvet personell (18), men lommeultralyd var ikke tilgjengelig under inklusjonen av pasienter til ACE 2-studien.

\section{Konklusjon}

Vår studie viser er at vaktleger ved Akershus universitetssykehus var like treffsikre når det gjaldt diagnosen akutt hjertesvikt som det som er rapportert fra ledende internasjonale sentre.
Vi takker alle dem som har bidratt til ACE 2-studien ved Akershus universitetssykehus, spesielt bidraget til datainnsamlingen fra Annika Lorentzen, Camilla Skjæret, Vigdis Bakkelund, Marit Jørgensen og Ragnhild Røysland.

ACE 2-studien ble finansiert av Norges forskningsråd via FORNY-programmet, med bevilgning til GC, TO og HR. Akershus universitetssykehus har også støttet ACE 2-studien med driftsmidler og studiepersonell.

Roche Diagnostics har støttet studien med NTproBNP-kit til redusert pris til TAH. TO har via Akershus universitetssykehus mottatt økonomisk støtte til forskningsprosjekter fra Astra Zeneca og Abbott Diagnostics og honorarer fra Abbott Diagnostics, Siemens Healthcare, Roche Diagnostics og Novartis. TO og HR har også mottatt forskningsstøtte via Akershus universitetssykehus fra Thermo Fisher BRAHMS, HyTest Ltd., Biomedica, Abbott Diagnostics, Roche Diagnostics og EuroDiagnostica. De andre forfatterne har ingen bindinger relevant for denne studien utover ansettelsesforhold for noen av medforfatterne ved Akershus universitetssykehus (JB, ADH, TAH, TO, HR).

Sponsorene hadde ingen rolle i følgende: design og gjennomføring av studien, datainnsamling, analyse eller fortolkning av data, produksjon av manuskript, gjennomlesing eller godkjenning.

\section{Jon Brynildsen (f. 1983)}

er lege og stipendiat. Han er medlem av Cardiothoracic Research Group, Akershus universitetssykehus, og skrev sin studentoppgave ved Universitetet i Oslo på data fra ACE 2-studien. Forfatter har fylt ut ICMJE-skjemaet og oppgir ingen interessekonflikter.

\section{Arne Didrik Høiseth (f. 1972)}

er ph.d., spesialist i indremedisin og lege i spesialisering i hjertesykdommer. Han er postdok tor tilknyttet Cardiothoracic Research Group ved Akershus universitetssykehus.

Forfatter har fylt ut ICMJE-skjemaet og oppgir ingen interessekonflikter.

\section{Ståle Nygård (f. 1976)}

har en doktorgrad i statistikk. Han er ansatt ved kjernefasilitet for bioinformatikk og leder helpdesken til den norske bioinformatikkplattformen (bioinfo.no).

Forfatter har fylt ut ICMJE-skjemaet og oppgir ingen interessekonflikter.

\section{Tor-Arne Hagve (f. 1953)}

er overlege i medisinsk biokjemi og professor II.

Forfatter har fylt ut ICMJE-skjemaet og oppgir ingen interessekonflikter utover det som fremgår til slutt i artikkelen.

\section{Geir Christensen (f. 1954)}

er dr. med., professor og har en mastergrad i helseadministrasjon. Han er leder av Center for Heart Failure Research og Norwegian PhD School of Heart Research (NORHEART) og gruppeleder i K.G. Jebsen-senteret.

Forfatter har fylt ut ICMJE-skjemaet og oppgir ingen interessekonflikter.

\section{Torbjørn Omland (f. 1962)}

er dr.med, Master of Public Health fra Harvard og spesialist i indremedisin og i hjertemedisin. Han er professor $1 \mathrm{i}$ indremedisin og gruppeleder i K.G. Jebsen-senteret. Omland var, sammen med Helge Røsjø, ansvarlig for planlegging og gjennomføring av ACE 2-studien. Forfatter har fylt ut ICMJE-skjemaet og oppgir følgende interessekonflikter: Utover det som fremgår til slutt i artikkelen har han mottatt honorar fra Abbott Diagnostics, Siemens Healthcare, Roche Diagnostics og Novartis.

\section{Helge Røsjø (f. 1975)}

er lege, ph.d., førsteamanuensis, avdelingssjef for forskning ved Akershus universitetssykehus og nestleder i K.G. Jebsen-senteret. Han har særlig interesse for hjertesvikt og leder Cardiothoracic Research Group, Akershus universitetssykehus. Røsjø var, sammen med Torbjørn Omland, ansvarlig for planlegging og gjennomføring av ACE 2-studien.

Forfatter har fylt ut ICMJE-skjemaet og oppgir følgende interessekonflikter: Utover det som fremgår til slutt i artikkelen har han mottatt foredragshonorar fra Novartis.

\section{Litteratur}

1. Green SM, Martinez-Rumayor A, Gregory SA et al. Clinical uncertainty, diagnostic accuracy, and outcomes in emergency department patients presenting with dyspnea. Arch Intern Med 2008; 168 . $741-8$.

2. Stevenson LW, Perloff JK. The limited reliability of physical signs for estimating hemodynamics in chronic heart failure. JAMA 1989: 261: 884-8.

3. Knudsen CW, Omland T, Clopton P et al. Diagnostic value of B-Type natriuretic peptide and chest radiographic findings in patients with acute dyspnea. Am J Med 2004; 116: 363-8.

4. Dao Q, Krishnaswamy P, Kazanegra R et al. Utility of B-type natriuretic peptide in the diagnosis of congestive heart failure in an urgent-care setting J Am Coll Cardiol 2001; 37: 379-85.

5. Januzzi JL Jr, Camargo CA, Anwaruddin $\mathrm{S}$ et al. The N-terminal Pro-BNP investigation of dyspnea in the emergency department (PRIDE) study. Am J Cardiol 2005; 95: 948-54.

6. McCullough PA, Nowak RM, McCord J et al. B-type natriuretic peptide and clinical judgment in emergency diagnosis of heart failure: analysis from Breathing Not Properly (BNP) Multinational Study. Circulation 2002; 106: 416-22

7. Moe GW. Howlett J, Januzzi JL et al. N-termina pro-B-type natriuretic peptide testing improves the management of patients with suspected acute heart failure: primary results of the Canadian prospective randomized multicenter IMPROVE-CHF study. Circulation 2007: 115: 3103-10.

8. Ray P, Birolleau S, Lefort Y et al. Acute respiratory failure in the elderly: etiology, emergency diagnosis and prognosis. Crit Care 2006; 10: R82. 
9. McMurray JJ, Adamopoulos S, Anker SD et al. ESC guidelines for the diagnosis and treatment of acute and chronic heart failure 2012. Eur Heart J 2012; 33: 1787-847.

10. Cockcroft DW, Gault MH. Prediction of creatinine clearance from serum creatinine. Nephron 1976; 16: 31-41.

11. DeLong ER, DeLong DM, Clarke-Pearson DL. Comparing the areas under two or more correlated receiver operating characteristic curves: a nonparametric approach. Biometrics 1988; 44: $837-45$.

12. Wang CS, FitzGerald JM, Schulzer M et al. Does this dyspneic patient in the emergency department have congestive heart failure? JAMA 2005; 294 : $1944-56$.

13. Jugdutt BI. Aging and heart failure: changing demographics and implications for therapy in the elderly. Heart Fail Rev 2010; 15: 401-5.

14. Thomas JT, Kelly RF, Thomas SJ et al. Utility of history, physical examination, electrocardiogram, and chest radiograph for differentiating normal from decreased systolic function in patients with heart failure. Am J Med 2002; 112: 437-45.

15. McCullough PA, Hollander JE, Nowak RM et al. Uncovering heart failure in patients with a history of pulmonary disease: rationale for the early use of B-type natriuretic peptide in the emergency department. Acad Emerg Med 2003; 10: 198-204.

16. Lancellotti P. Price S, Edvardsen T et al. The use of echocardiography in acute cardiovascular care: recommendations of the European Association of Cardiovascular Imaging and the Acute Cardiovascular Care Association. Eur Heart J Acute Cardiovasc Care 2015; 4: 3-5.

17. Laursen CB, Sloth E, Lassen AT et al. Point-ofcare ultrasonography in patients admitted with respiratory symptoms: a single-blind, randomised controlled trial. Lancet Respir Med 2014; 2: 638-46.

18. Mjølstad OC, Dalen H, Graven T et al. Routinely adding ultrasound examinations by pocket-sized ultrasound devices improves inpatient diagnostics in a medical department. Eur J Intern Med 2012; 23: 185-91.

Mottatt 23.9. 2014, første revisjon innsendt 13.3. 2015, godkjent 19.8. 2015. Redaktør: Tor Rosness. 